\title{
Effects of Dental Hygienists Job Stress on Somatization in
}

\section{an Area}

\author{
Mi-Jeong $\mathrm{Kim}^{\dagger}$, Hyeon-Sun Kim, and Cha-Young Lim \\ Department of Dental Hygiene, Vision College of Jeonju, Jeonju 55069, Korea
}

\begin{abstract}
Background: This study aims to analyze the job stress of dental hygienists and the factors affecting somatization and to provide basic data for effectively managing job stress and somatization of dental hygienists.

Methods: In this study, the data collected from 208 dental hygienists working in Jeollabuk-do Province were analyzed. Job stress was investigated using a questionnaire with 43 questions. In addition, the degree of somatization was evaluated through a simplified psychotherapy examination (Symptom Check List-90-Revision).

Results: Age, employment history, position, average monthly income, night duty execution status, and perceived health status were significantly associated with job stress $(p<0.05)$. The job stress sub-items scores based on general characteristics showed significance in 'workload' for those working a five-day workweek and perceived health status $(p<0.05)$. Age, average monthly income, and perceived health status were noted in 'role conflict as a professional'. In 'lack of expertise and skill', it was noted that age, employment history, position, income, and night clinic were implemented. In 'improper treatment and interpersonal issues', level of education and perceived health status were significant $(p<0.05)$. The higher the job stress, the higher the somatization symptom score $(p<0.05)$, and the higher the job stress component, the higher the somatization symptom score $(p<0.01)$. Conclusion: The job stress of dental hygienists should be reduced, and the symptoms of somatization should be mitigated. To improve the quality of medical services and the work efficiency of dental hygienists, proper treatment and compensation systems should be implemented for them to take pride as professional. Further, programs and regulations on mitigating job stress and somatization symptoms should be developed.
\end{abstract}

Key Words: Dental hygienist, Job stress, Somatic symptom

\section{Introduction}

With the emergence of the fourth Industrial Revolution, the medical service industry is growing rapidly along with advancements in medical technology. Developments in medical technology require professionalism in humanistic care for not only providing treatment but also interactive service based on integrity and expertise to guarantee a better quality of life for people ${ }^{1)}$. The quality of medical service is expected to continue improving as the national economic level increase ${ }^{2)}$, including the dental health industry. Dental hygienists provide an important dental service while taking a crucial role in determining the quality of dental health services ${ }^{3)}$; thus, they are expected to have more expertise in carrying out professional tasks ${ }^{4}$. As expected by the society, the dental health industry is specialized and compartmentalized, in which the tasks and roles of dental hygienists are expanded and the required levels of technique and knowledge have also increased. Dental clinics are becoming larger while the services are more specialized, where the scope of work has expanded from treatment assistance to overall dental procedures, thus generating an overwhelming workload and competition between dental clinics ${ }^{5)}$. Accordingly, dental hygienists are highly stressed and face constant pressure of improving self-competence. Nevertheless, dental hygienists are ex- 
periencing a high level of work stress, as they are expected to handle an overwhelming workload ${ }^{6}$. Work stress refers to harmful physical and psychological reactions caused when the ability, resources, and demands of a worker do not correspond with their duty ${ }^{7}$. Furthermore, high work stress has a significantly negative effect on the organization and its members ${ }^{8}$. Being constantly exposed to high work stress has been reported to cause somatization", wherein an individual develops physical discomfort or symptoms without a reasonable cause and seeks medical help by considering it as a physical illness ${ }^{10}$. Chronic work stress commonly causes various somatization symptoms such as headache, abdominal pain, indigestion, and fatigue. Somatization symptoms can easily become chronic if appropriate treatment is not given early, which eventually makes treatment difficult and causes a decrease in the ability to perform job-related duties ${ }^{11-13)}$. Somatization leads to a reduced efficiency of an organization due to the high turnover rate and the absence rate of employees at the organization level and increased job dissatisfaction, alcohol and drug abuse, and other physical problems at the individual level ${ }^{14)}$. Moreover, stress of the workers in medical services directly influences service provision in the healthcare industry, ultimately affecting the quality of healthcare services provided to patients ${ }^{15}$.

Job stress in dental hygienists is currently an emerging issue owing to their need to acquire new skills, overwhelming workload, uncertain division of duties, complicated workplace relationships or working conditions, and the diverse service demands of their patients ${ }^{16)}$. In this study, therefore, by analyzing the factors affecting somatization with regard to job stress among dental hygienists, we provide basic data for effectively managing job stress and somatization of dental hygienists.

\section{Materials and Methods}

\section{Research subjects}

The subjects of this study were selected by convenience sampling among licensed dental hygienists currently working in Jeollabuk-do. The study period was from January 28 to February 28, 2019. Using G*POWER 3.1, minimum sample size was calculated as 204 , based on a significance level of 0.05 , effect size of 0.15 , and statistical power of 0.95 . To minimize standard error and considering sampling bias or a $10 \%$ withdrawal rate, a total of 220 subjects who provided informed consent to participate were finally selected. The subjects completed a structured survey using Google in a self-reporting manner. Excluding 12 surveys containing numerous missing values, a total of 208 surveys were selected for final analysis.

\section{Research tools}

To measure the level of job stress among dental hygienists, the tool for measuring job stress, as used for Koreans and developed by Chang et al. ${ }^{17)}$, was revised to be appropriate for dental hygienists by referring to the survey developed by $\mathrm{Oh}^{18)}$. For this study, job stress in dental hygienists was subdivided into four subcategories including 10 items on 'overwork,' 6 items on 'role conflict as a professional,' 10 items on 'lack of expertise and skill,' and 17 items on 'improper treatment and interpersonal issues,' for a total of 43 items. Reliability was tested for internal consistency of the tool, in which Cronbach's $\alpha$ was 0.950. Values of Cronbach's $\alpha$ for each of the four subcategories of job stress were as follows: 0.796 for 'overwork,' 0.835 for 'role conflict as a professional,' 0.916 for 'lack of expertise and skill,' and 0.927 for 'improper treatment and interpersonal issues.'

To identify the severity of somatization symptoms, the Symptom Checklist-90-Revision ${ }^{19)}$ was used, in which only 12 items associated with the somatization scale were used in this study. A reliability analysis revealed a Cronbach's $\alpha$ of 0.865 .

Both job stress and somatization symptoms were scored based on a 5-point Likert scale. As items are negatively formulated, a higher score indicates a higher stress level and more severe somatization symptoms.

As for the general characteristics of the subjects, age, level of education, employment history, position, five-day workweek, night duty execution status, average monthly income, and perceived health status were examined.

\section{Data analysis}

An independent t-test and a one-way analysis of 
Table 1. Job Stressand Somatization according to Demographic Variable

\begin{tabular}{|c|c|c|c|c|c|c|}
\hline Item & Job stress & Overwork & $\begin{array}{l}\text { Professional } \\
\text { role conflict } \\
\text { experience }\end{array}$ & $\begin{array}{c}\text { Lack of } \\
\text { expertise and } \\
\text { skill }\end{array}$ & $\begin{array}{c}\text { Improper } \\
\text { treatment and } \\
\text { interpersonal } \\
\text { issues }\end{array}$ & Somatization \\
\hline Total & $\begin{array}{c}180 \\
161.00 \pm 24.05\end{array}$ & $\begin{array}{c}196 \\
38.40 \pm 5.56\end{array}$ & $\begin{array}{c}200 \\
21.61 \pm 4.39\end{array}$ & $\begin{array}{c}198 \\
35.46 \pm 7.26\end{array}$ & $\begin{array}{c}188 \\
65.90 \pm 11.45\end{array}$ & $\begin{array}{c}198 \\
47.53 \pm 8.01\end{array}$ \\
\hline \multicolumn{7}{|l|}{ Age (y) } \\
\hline $23 \sim 25$ & $\begin{array}{c}60 \\
168.57 \pm 20.88^{b}\end{array}$ & $\begin{array}{c}62 \\
39.55 \pm 5.16\end{array}$ & $\begin{array}{c}62 \\
23.19 \pm 3.90^{\mathrm{b}}\end{array}$ & $\begin{array}{c}60 \\
38.60 \pm 6.80^{\mathrm{b}}\end{array}$ & $\begin{array}{c}60 \\
66.70 \pm 10.65^{\mathrm{b}}\end{array}$ & $\begin{array}{c}62 \\
47.68 \pm 8.35^{\mathrm{a}}\end{array}$ \\
\hline $26 \sim 30$ & $\begin{array}{c}62 \\
156.45 \pm 23.45^{\mathrm{a}}\end{array}$ & $\begin{array}{c}66 \\
37.85 \pm 5.98\end{array}$ & $\begin{array}{c}66 \\
20.64 \pm 4.21^{\mathrm{a}}\end{array}$ & $\begin{array}{c}66 \\
34.30 \pm 5.88^{\mathrm{ab}}\end{array}$ & $\begin{array}{c}62 \\
64.71 \pm 11.92^{\mathrm{ab}}\end{array}$ & $\begin{array}{c}68 \\
47.26 \pm 8.31^{\mathrm{a}}\end{array}$ \\
\hline $31 \sim 35$ & $\begin{array}{c}44 \\
163.85 \pm 27.42^{\mathrm{b}}\end{array}$ & $\begin{array}{c}42 \\
38.90 \pm 5.89\end{array}$ & $\begin{array}{c}46 \\
21.48 \pm 4.99^{\mathrm{ab}}\end{array}$ & $\begin{array}{c}46 \\
34.91 \pm 8.36^{\mathrm{ab}}\end{array}$ & $\begin{array}{c}44 \\
69.00 \pm 11.45^{\mathrm{b}}\end{array}$ & $\begin{array}{c}46 \\
47.26 \pm 8.49^{\mathrm{a}}\end{array}$ \\
\hline $36 \sim 40$ & $\begin{array}{c}10 \\
147.00 \pm 27.85^{\mathrm{a}}\end{array}$ & $\begin{array}{c}12 \\
34.83 \pm 4.28^{\mathrm{a}}\end{array}$ & $\begin{array}{c}12 \\
20.33 \pm 4.42^{\mathrm{a}}\end{array}$ & $\begin{array}{c}12 \\
31.50 \pm 7.28^{\mathrm{a}}\end{array}$ & $\begin{array}{c}10 \\
62.40 \pm 13.82^{\mathrm{ab}}\end{array}$ & $\begin{array}{c}10 \\
46.40 \pm 4.35^{\mathrm{a}}\end{array}$ \\
\hline $41 \sim 50$ & $\begin{array}{c}12 \\
147.33 \pm 9.64^{\mathrm{a}}\end{array}$ & $\begin{array}{c}14 \\
37.43 \pm 3.67\end{array}$ & $\begin{array}{c}14 \\
20.71 \pm 3.54^{\mathrm{a}}\end{array}$ & $\begin{array}{c}14 \\
32.71 \pm 7.29^{\mathrm{ab}}\end{array}$ & $\begin{array}{c}12 \\
59.67 \pm 7.74^{\mathrm{a}}\end{array}$ & $\begin{array}{c}12 \\
50.17 \pm 4.69^{\mathrm{ab}}\end{array}$ \\
\hline $\mathrm{p}$ & 0.003 & 0.059 & 0.010 & 0.001 & 0.068 & 0.804 \\
\hline \multicolumn{7}{|l|}{ Level of education } \\
\hline College & $\begin{array}{c}124 \\
160.43 \pm 26.37\end{array}$ & $\begin{array}{c}126 \\
38.92 \pm 6.09\end{array}$ & $\begin{array}{c}130 \\
21.60 \pm 4.47\end{array}$ & $\begin{array}{c}128 \\
35.39 \pm 8.07\end{array}$ & $\begin{array}{c}124 \\
64.71 \pm 12.13\end{array}$ & $\begin{array}{c}132 \\
47.35 \pm 8.10\end{array}$ \\
\hline$\geq$ University & $\begin{array}{c}64 \\
162.03 \pm 19.31\end{array}$ & $\begin{array}{c}70 \\
37.46 \pm 4.34\end{array}$ & $\begin{array}{c}70 \\
21.63 \pm 4.26\end{array}$ & $\begin{array}{c}70 \\
35.60 \pm 5.52\end{array}$ & $\begin{array}{c}64 \\
68.22 \pm 9.67\end{array}$ & $\begin{array}{c}66 \\
47.88 \pm 7.89\end{array}$ \\
\hline $\mathrm{p}$ & 0.067 & 0.077 & 0.965 & 0.847 & 0.046 & 0.662 \\
\hline \multicolumn{7}{|l|}{ Employment history (y) } \\
\hline $1 \sim 3$ & $\begin{array}{c}72 \\
165.28 \pm 22.19\end{array}$ & $\begin{array}{c}76 \\
38.71 \pm 5.14^{\mathrm{b}}\end{array}$ & $\begin{array}{c}76 \\
22.34 \pm 4.35^{\mathrm{b}}\end{array}$ & $\begin{array}{c}72 \\
38.36 \pm 6.42^{b}\end{array}$ & $\begin{array}{c}74 \\
65.24 \pm 10.94^{\mathrm{ab}}\end{array}$ & $\begin{array}{c}76 \\
46.53 \pm 8.45^{\mathrm{a}}\end{array}$ \\
\hline $4 \sim 6$ & $\begin{array}{c}38 \\
158.33 \pm 26.52^{\mathrm{ab}}\end{array}$ & $\begin{array}{c}42 \\
38.10 \pm 6.43^{b}\end{array}$ & $\begin{array}{c}44 \\
21.77 \pm 3.99^{b}\end{array}$ & $\begin{array}{c}44 \\
34.55 \pm 6.46^{\mathrm{ab}}\end{array}$ & $\begin{array}{c}38 \\
65.74 \pm 13.36^{\mathrm{ab}}\end{array}$ & $\begin{array}{c}44 \\
47.86 \pm 9.00^{\mathrm{ab}}\end{array}$ \\
\hline $7 \sim 9$ & $\begin{array}{c}22 \\
159.00 \pm 24.52^{\mathrm{ab}}\end{array}$ & $\begin{array}{c}22 \\
35.82 \pm 4.74^{\mathrm{a}}\end{array}$ & $\begin{array}{c}24 \\
21.08 \pm 4.42^{\mathrm{a}}\end{array}$ & $\begin{array}{c}24 \\
33.92 \pm 7.64^{\mathrm{ab}}\end{array}$ & $\begin{array}{c}22 \\
68.64 \pm 10.79^{b}\end{array}$ & $\begin{array}{c}22 \\
46.55 \pm 10.37^{\mathrm{a}}\end{array}$ \\
\hline$\geq 10$ & $\begin{array}{c}38 \\
150.83 \pm 24.68^{\mathrm{a}}\end{array}$ & $\begin{array}{c}38 \\
38.21 \pm 5.79^{b}\end{array}$ & $\begin{array}{c}40 \\
20.25 \pm 4.58^{\mathrm{a}}\end{array}$ & $\begin{array}{c}40 \\
31.80 \pm 7.95^{\mathrm{a}}\end{array}$ & $\begin{array}{c}38 \\
62.53 \pm 11.31^{\mathrm{a}}\end{array}$ & $\begin{array}{c}38 \\
48.21 \pm 4.33^{\mathrm{b}}\end{array}$ \\
\hline $\mathrm{p}$ & 0.034 & 0.205 & 0.092 & $<0.001$ & 0.260 & 0.677 \\
\hline \multicolumn{7}{|l|}{ Position } \\
\hline Intern, contract worker & $\begin{array}{c}20 \\
164.73 \pm 16.93^{b}\end{array}$ & $\begin{array}{c}20 \\
38.20 \pm 5.08^{b}\end{array}$ & $\begin{array}{c}20 \\
22.60 \pm 4.31^{\mathrm{b}}\end{array}$ & $\begin{array}{c}20 \\
38.10 \pm 5.76^{\mathrm{b}}\end{array}$ & $\begin{array}{c}20 \\
65.80 \pm 8.62^{\mathrm{ab}}\end{array}$ & $\begin{array}{c}20 \\
44.70 \pm 5.79^{\mathrm{a}}\end{array}$ \\
\hline Regular (worker) & $\begin{array}{c}116 \\
164.96 \pm 23.91^{\mathrm{b}}\end{array}$ & $\begin{array}{c}126 \\
38.95 \pm 5.53^{\mathrm{b}}\end{array}$ & $\begin{array}{c}126 \\
21.90 \pm 4.26^{\mathrm{ab}}\end{array}$ & $\begin{array}{c}124 \\
36.73 \pm 7.02^{\mathrm{b}}\end{array}$ & $\begin{array}{c}116 \\
67.33 \pm 11.79^{b}\end{array}$ & $\begin{array}{c}126 \\
47.94 \pm 8.57^{\mathrm{b}}\end{array}$ \\
\hline Person in charge head of a department & $\begin{array}{c}52 \\
150.21 \pm 23.99^{\mathrm{a}}\end{array}$ & $\begin{array}{c}50 \\
37.08 \pm 5.69^{\mathrm{a}}\end{array}$ & $\begin{array}{c}54 \\
20.56 \pm 4.59^{\mathrm{a}}\end{array}$ & $\begin{array}{c}54 \\
31.59 \pm 6.93^{\mathrm{a}}\end{array}$ & $\begin{array}{c}52 \\
62.77 \pm 11.19^{a}\end{array}$ & $\begin{array}{c}52 \\
47.62 \pm 7.20^{\mathrm{b}}\end{array}$ \\
\hline $\mathrm{p}$ & 0.001 & 0.129 & 0.094 & $<0.001$ & 0.057 & 0.244 \\
\hline \multicolumn{7}{|l|}{ Average monthly income } \\
\hline$\leq 200$ & $\begin{array}{c}80 \\
166.56 \pm 21.05^{\mathrm{b}}\end{array}$ & $\begin{array}{c}84 \\
39.14 \pm 4.79^{b}\end{array}$ & $\begin{array}{c}86 \\
22.65 \pm 3.95^{\mathrm{b}}\end{array}$ & $\begin{array}{c}86 \\
37.81 \pm 6.62^{\mathrm{a}}\end{array}$ & $\begin{array}{c}80 \\
66.85 \pm 10.56^{\mathrm{b}}\end{array}$ & $\begin{array}{c}84 \\
46.98 \pm 8.20^{\mathrm{a}}\end{array}$ \\
\hline $201 \sim 250$ & $\begin{array}{c}76 \\
157.14 \pm 26.25^{\mathrm{a}}\end{array}$ & $\begin{array}{c}78 \\
37.92 \pm 6.39^{\mathrm{a}}\end{array}$ & $\begin{array}{c}78 \\
20.77 \pm 4.73^{\mathrm{a}}\end{array}$ & $\begin{array}{c}76 \\
33.13 \pm 7.31^{\mathrm{ab}}\end{array}$ & $\begin{array}{c}76 \\
65.34 \pm 12.25^{\mathrm{ab}}\end{array}$ & $\begin{array}{c}80 \\
48.20 \pm 7.77^{\mathrm{b}}\end{array}$ \\
\hline$\geq 251$ & $\begin{array}{c}34 \\
155.80 \pm 23.63^{\mathrm{a}}\end{array}$ & $\begin{array}{c}36 \\
37.64 \pm 5.21^{\mathrm{a}}\end{array}$ & $\begin{array}{c}36 \\
20.94 \pm 4.17^{\mathrm{a}}\end{array}$ & $\begin{array}{c}32 \\
34.78 \pm 7.07^{\mathrm{b}}\end{array}$ & $\begin{array}{c}34 \\
64.88 \pm 11.82^{\mathrm{a}}\end{array}$ & $\begin{array}{c}36 \\
47.29 \pm 8.22^{\mathrm{ab}}\end{array}$ \\
\hline $\mathrm{p}$ & 0.023 & 0.261 & 0.013 & $<0.001$ & 0.613 & 0.612 \\
\hline
\end{tabular}


Table 1. Continued

\begin{tabular}{|c|c|c|c|c|c|c|}
\hline Item & Job stress & Overwork & $\begin{array}{l}\text { Professional } \\
\text { role conflict } \\
\text { experience }\end{array}$ & $\begin{array}{c}\text { Lack of } \\
\text { expertise and } \\
\text { skill }\end{array}$ & $\begin{array}{c}\text { Improper } \\
\text { treatment and } \\
\text { interpersonal } \\
\text { issues }\end{array}$ & Somatization \\
\hline \multicolumn{7}{|l|}{ The five-day workweek } \\
\hline \multirow[t]{2}{*}{ Existence } & 140 & 144 & 146 & 146 & 140 & 144 \\
\hline & $160.48 \pm 25.25$ & $37.85 \pm 5.58$ & $21.36 \pm 4.37$ & $35.92 \pm 7.04$ & $65.81 \pm 11.91$ & $46.97 \pm 8.37$ \\
\hline \multirow[t]{2}{*}{ Nonexistence } & 48 & 52 & 54 & 52 & 48 & 54 \\
\hline & $162.52 \pm 20.35$ & $39.92 \pm 5.27$ & $22.30 \pm 4.39$ & $34.19 \pm 7.78$ & $66.17 \pm 10.08$ & $49.00 \pm 6.82$ \\
\hline $\mathrm{p}$ & 0.062 & 0.021 & 0.179 & 0.142 & 0.855 & 0.113 \\
\hline \multicolumn{7}{|l|}{ Night duty } \\
\hline Absence & $\begin{array}{c}50 \\
157.84 \pm 20.26^{\mathrm{a}}\end{array}$ & $\begin{array}{c}58 \\
38.62 \pm 4.77^{\mathrm{b}}\end{array}$ & $\begin{array}{c}56 \\
21.82 \pm 4.27^{\mathrm{b}}\end{array}$ & $\begin{array}{c}56 \\
33.29 \pm 7.16^{\mathrm{a}}\end{array}$ & $\begin{array}{c}50 \\
64.40 \pm 10.74^{\mathrm{a}}\end{array}$ & $\begin{array}{c}58 \\
47.55 \pm 6.70^{\mathrm{a}}\end{array}$ \\
\hline $8: 00 \mathrm{pm} \sim 8: 30 \mathrm{pm}$ & $\begin{array}{c}100 \\
163.60 \pm 26.72^{b}\end{array}$ & $\begin{array}{c}102 \\
38.57 \pm 6.16^{\mathrm{b}}\end{array}$ & $\begin{array}{c}106 \\
21.74 \pm 4.59^{\mathrm{b}}\end{array}$ & $\begin{array}{c}106 \\
36.68 \pm 7.92^{\mathrm{ab}}\end{array}$ & $\begin{array}{c}100 \\
67.26 \pm 11.56^{\mathrm{b}}\end{array}$ & $\begin{array}{c}104 \\
47.65 \pm 8.42^{\mathrm{a}}\end{array}$ \\
\hline $9: 00 \mathrm{pm} \sim 9: 30 \mathrm{pm}$ & $\begin{array}{c}38 \\
158.29 \pm 20.75^{\mathrm{a}}\end{array}$ & $\begin{array}{c}36 \\
37.56 \pm 4.98^{\mathrm{a}}\end{array}$ & $\begin{array}{c}38 \\
20.95 \pm 4.01^{\mathrm{a}}\end{array}$ & $\begin{array}{c}36 \\
35.28 \pm 3.97^{\mathrm{b}}\end{array}$ & $\begin{array}{c}38 \\
64.32 \pm 11.91^{\mathrm{a}}\end{array}$ & $\begin{array}{c}36 \\
47.11 \pm 8.91^{\mathrm{a}}\end{array}$ \\
\hline $\mathrm{p}$ & 0.030 & 0.604 & 0.584 & 0.017 & 0.224 & 0.941 \\
\hline \multicolumn{7}{|l|}{ Perceived health status } \\
\hline Poor & $\begin{array}{c}60 \\
167.55 \pm 17.59^{\mathrm{b}}\end{array}$ & $\begin{array}{c}66 \\
39.73 \pm 4.68^{\mathrm{b}}\end{array}$ & $\begin{array}{c}68 \\
23.03 \pm 3.02^{\mathrm{b}}\end{array}$ & $\begin{array}{c}68 \\
35.88 \pm 6.68^{\mathrm{b}}\end{array}$ & $\begin{array}{c}60 \\
69.30 \pm 10.04^{\mathrm{b}}\end{array}$ & $\begin{array}{c}66 \\
52.03 \pm 5.78^{\mathrm{c}}\end{array}$ \\
\hline Normal & $\begin{array}{c}100 \\
160.57 \pm 25.32^{\mathrm{ab}}\end{array}$ & $\begin{array}{c}106 \\
38.53 \pm 5.57^{\mathrm{b}}\end{array}$ & $\begin{array}{c}104 \\
21.31 \pm 4.85^{\mathrm{ab}}\end{array}$ & $\begin{array}{c}102 \\
35.55 \pm 7.44^{\mathrm{b}}\end{array}$ & $\begin{array}{c}100 \\
65.16 \pm 11.56^{\mathrm{ab}}\end{array}$ & $\begin{array}{c}104 \\
46.29 \pm 7.81^{\mathrm{b}}\end{array}$ \\
\hline Good & $\begin{array}{c}28 \\
146.92 \pm 26.75^{\mathrm{a}}\end{array}$ & $\begin{array}{c}24 \\
34.17 \pm 5.88^{\mathrm{a}}\end{array}$ & $\begin{array}{c}28 \\
19.29 \pm 4.28^{\mathrm{a}}\end{array}$ & $\begin{array}{c}28 \\
34.14 \pm 8.03^{\mathrm{a}}\end{array}$ & $\begin{array}{c}28 \\
61.29 \pm 12.17^{\mathrm{a}}\end{array}$ & $\begin{array}{c}28 \\
41.50 \pm 7.87^{\mathrm{a}}\end{array}$ \\
\hline $\mathrm{p}$ & 0.002 & $<0.001$ & $<0.001$ & 0.560 & 0.005 & $<0.001$ \\
\hline
\end{tabular}

Values are presented as $\mathrm{n}$ or mean \pm standard deviation.

${ }^{a-c}$ The same characters are not significant by Scheffe multiple comparison $(p<0.05)$.

variance were performed to examine differences in job stress and somatization symptoms according to general characteristics, and the Scheffé test was conducted as a post-hoc test. Pearson's correlation coefficients were analyzed to examine the correlation between job stress and somatization symptoms. Furthermore, multiple linear regression analysis was performed with set variables to analyze factors influencing somatization symptoms. The collected data were analyzed using PASW Statistics ver. 18.0 (IBM Corp., Armonk, NY, USA). The significance level $(\alpha)$ of statistical tests was set at 0.05 .

\section{Results}

\section{Job stress and somatization symptoms according to general characteristics}

The differences in job stress and somatization symptoms according to general characteristics are shown in Table 1.
In terms of the general characteristics, the subjects' age, employment history, position, income, night duty execution status, and perceived health status were significantly associated with job stress $(\mathrm{p}<0.05)$. Subjects between 23 and 25 years of age had the highest job stress scores, whereas those between 36 and 40 years of age had the lowest job stress scores. Job stress scores were higher among subjects with short employment history, while those in a lower position had a high level of job stress. Subjects with a lower income had a higher level of job stress, and those with night duty for 8:00 pm to 8:30 pm also had a high level of job stress. The level of job stress was high for subjects with a poor perceived health status.

A five-day workweek and perceived health status were significantly associated with 'overwork' $(p<0.05)$; age, income, and perceived health status with 'role conflict as a professional'; age, employment history, position, income, night duty execution status with 'lack of expertise and 
skill,' and level of education and perceived health status with 'improper treatment and interpersonal issues' $(\mathrm{p}<$ 0.05).

With regard to 'overwork,' subjects who did not have a five-day workweek and with a poor perceived health status had a higher stress score. Subjects between 23 and 25 years of age who had 2 million Korean won or less of monthly income or who had a poor perceived health status had a high score for 'role conflict as a professional.' Subjects between 23 and 25 years of age had the highest scores for 'lack of expertise and skills.' Subjects with a poor perceived health status also had high scores for emotional disharmony and damage in customer service. Subjects at lower positions and with short employment history, 2 million Korean won or less of monthly income, and night duty for 8 to 8.5 hours had a high score for 'lack of expertise and skill.' Subjects with a University or with a poor perceived health status had a high score for 'improper treatment and interpersonal issues.'

Perceived health status was significantly associated with somatization symptoms $(\mathrm{p}<0.05)$. The score for somatization symptoms was high among subjects with a poor perceived health status.

\section{Correlation between job stress and somatization symptoms}

The correlation data between job stress and somatization symptoms are shown in Table 2.

Overall job stress and all subcategories of job stress exhibited significant correlations $(\mathrm{p}<0.001)$.

As the scores for job stress and its subcategories increased, so did the score for somatization symptoms.

\section{Factors influencing somatization symptoms in terms of job stress and sociodemographic characteristics}

The factors influencing somatization symptoms in terms of job stress and sociodemographic characteristics are shown in Table 3.

In Model 1, where the subcategories of job stress were

Table 2. Correlation between Job Stress and Somatization

\begin{tabular}{cccccc}
\hline Item & Job stress & Overwork & $\begin{array}{c}\text { Professional role } \\
\text { conflict experience }\end{array}$ & $\begin{array}{c}\text { lack of } \\
\text { expertise and skill }\end{array}$ & $\begin{array}{c}\text { Improper treatment and } \\
\text { interpersonal issues }\end{array}$ \\
\hline Somatization & $0.417 * * *$ & $0.430 * * *$ & $0.271^{* * *}$ & $0.234^{* * *}$ & $0.394 * * *$ \\
\hline
\end{tabular}

$* * * \mathrm{p}<0.001$ by pearson's correlation analysis.

Table 3. Effects of Job Stress, Demographic Variable on Somatization

\begin{tabular}{|c|c|c|c|c|c|c|}
\hline \multirow{2}{*}{ Item } & \multicolumn{2}{|c|}{ Model 1} & \multicolumn{2}{|c|}{ Model 2} & \multicolumn{2}{|c|}{ Model 3} \\
\hline & $\beta$ & $\mathrm{p}$ & $\beta$ & $\mathrm{p}$ & $\beta$ & $\mathrm{p}$ \\
\hline Overwork & 0.178 & 0.155 & & & 0.152 & 0.108 \\
\hline Professional role conflict experience & -0.090 & 0.425 & & & -0.131 & 0.175 \\
\hline Lack of expertise and skill & -0.148 & 0.278 & & & 0.054 & 0.584 \\
\hline Improper treatment and interpersonal issues & 0.407 & 0.050 & & & 0.230 & 0.021 \\
\hline Age & & & -0.167 & 0.200 & -0.232 & 0.090 \\
\hline Level of education & & & -0.085 & 0.253 & -0.055 & 0.494 \\
\hline Employment history & & & -0.038 & 0.797 & 0.079 & 0.625 \\
\hline Post position & & & 0.148 & 0.153 & 0.180 & 0.084 \\
\hline Average monthly income & & & 0.225 & 0.033 & 0.071 & 0.568 \\
\hline The five-day workweek & & & 0.169 & 0.025 & 0.148 & 0.053 \\
\hline Night duty & & & 0.063 & 0.410 & -0.010 & 0.901 \\
\hline Perceived health status & & & -0.519 & $<0.001$ & -0.482 & $<0.001$ \\
\hline $\mathrm{R}^{2}$ & \multicolumn{2}{|c|}{0.212} & \multicolumn{2}{|c|}{0.312} & \multicolumn{2}{|c|}{0.397} \\
\hline Adjusted $\mathrm{R}^{2}$ & \multicolumn{2}{|c|}{0.194} & \multicolumn{2}{|c|}{0.269} & \multicolumn{2}{|c|}{0.336} \\
\hline
\end{tabular}

Model 1: subcategories of job stress, Model 2: demographic variable, Model 3: subcategories of job stress+demographic variable. 
input as independent variables, a high score for 'improper treatment and interpersonal issues' led to more severe somatization symptoms.

In Model 2, where the sociodemographic characteristics were input as independent variables, subjects who had a higher income, worked for more than five days a week, and had a poor perceived health status had more severe somatization symptoms.

In Model 3, where the subcategories of job stress and sociodemographic characteristics were input as independent variables, subjects with high scores for 'improper treatment and interpersonal issues' and poor perceived health status had more severe somatization symptoms. The explanatory power of the model was $39.7 \%$.

\section{Discussion}

Medical service environments are rapidly changing with increasing level of knowledge and skills to be acquired due to advancements in medical technology. As medical institutions grow, competition intensifies, consumer demands increase, and duties become more specialized and compartmentalized ${ }^{5)}$. Such changes have become part of daily life for dental hygienists. These circumstances cause extreme stress, beyond the usual responsibilities and pressure. When individuals are overly exposed to stress, their physical and psychological health are at risk and job satisfaction is reduced, and so job stress management is significantly important ${ }^{14)}$. This study was conducted to provide basic data for effectively managing job stress and somatization of dental hygienists by analyzing factors affecting somatization with regard to the job stress of dental hygienists.

In this study, subjects between 23 and 25 years of age in lower positions, with shorter employment history, lower income, and who had night duty had a high level of job stress. In several previous studies ${ }^{18,20-22)}$, individuals with a higher income had a higher job satisfaction, which corresponds to the findings of the study by Lee et al. ${ }^{23}$, wherein those with a lower income had a higher level of job stress. Accordingly, a compensation system for personal competence should be established such that individuals can develop a sense of pride for their duty and role, thereby reducing job stress. In the study by Lee et al. ${ }^{23)}$, subjects between 24 and 26 years of age with a short employment history had a high level of job stress, which corresponds to the results of this study. Subjects with a longer employment history have better work proficiency and judgment skills, thus having a lower level of job stress. In contrast, younger subjects with a shorter employment history tend to have a higher level of job stress due to mental and physical stress caused by lack of experience and increased workload. Lower income was also associated with a higher level of job stress. This may be due to an association between employment history and age, in which younger subjects with a shorter employment history in turn generated a lower income. Out of a possible 60 points in the score for somatization symptoms in this study, the average score of the subjects was 47.53 points, which is fairly high. Hence, a measure for alleviating somatization symptoms is needed.

The results of this study showed that poor perceived health status and the presence of somatization symptoms caused a high level of job stress, which corresponds with the findings of Hong et al. ${ }^{6}$ Differences in levels of job stress affect perceived health status, which eventually leads to somatization symptoms; hence, an effective stress management strategy is needed. When the subcategories of job stress and sociodemographic characteristics were input as independent variables to examine their effects on somatization symptoms, those with a higher score for improper treatment and interpersonal issues had more severe somatization symptoms. This implies that dental hygienists should be encouraged and acknowledged for performing their duties to help them feel a sense of achievement. Moreover, appropriate treatment and compensation should be provided to give them a sense of pride as professionals. When sociodemographic characteristics were input as independent variables, those who worked more than five days a week and had poor perceived health status had more severe somatization symptoms, thus interfering with efficiently performing their duties. Jeong et al. ${ }^{24)}$ reported that a five-day workweek improves job satisfaction while reducing the level of stress. Therefore, dental clinics should change working environments by adopting a five-day workweek to improve the performance 
of dental hygienists. When the subcategories of job stress and sociodemographic characteristics were input as independent variables, those with a poor perceived health status had more severe somatization symptoms, which corresponds to the findings by Hong et al. ${ }^{6)}$ Job stress has a negative effect on psychological health as well as physical health; hence, job stress is closely related to the overall health of a person. These problems can eventually bring decreased productivity and a loss of workforce. In the study by Lee and Yoon ${ }^{25)}$, job stress has been reported to deteriorate mental and physical health while negatively affecting enthusiasm for work, which is similar to the results of this study.

The limitation of this study is that the data were collected from dental hygienists in a certain region, and so the study results cannot be generalized. Furthermore, this research was a cross-sectional study through which the causal relationship between the variables could not verified. In future studies, more systematic results and the correlation between job stress of dental hygienists and somatization symptoms should be further examined by using various sampling methods. Nonetheless, the results of this study can be used as basic data for developing programs for mitigating job stress and somatization symptoms by identifying factors causing stress and somatization symptoms in dental hygienists, who are the core part of medical services.

Currently, there is lack of regulations or restrictions for managing job stress and somatization symptoms in dental hygienists, let alone the awareness of the risk of such problems. A high level of job stress and lasting somatization symptoms in dental hygienists will reduce the quality of service and care provided to patients as well as the management of dental clinics, while negatively affecting the mental, physical, and social health of dental hygienists. Accordingly, programs and regulations on mitigating job stress and somatization symptoms in dental hygienists, who are vulnerable to emotional labor, should be developed to improve the quality of medical service and work efficiency. Proper treatment and compensation systems should also be provided so as to help dental hygienists develop a sense of pride as professionals.

\section{Notes}

\section{Conflict of interest}

No potential conflict of interest relevant to this article was reported.

\section{Ethical approval}

This study was approved by the institutional review board of Won Kwang University (IRB No. WKIRB201901-SB-006).

\section{Author contributions}

Conceptualization: Mi-Jeong Kim, Hyeon-Sun Kim. Data acquisition: Cha-Young Lim. Formal analysis: Cha-Young Lim. Funding: Mi-Jeong Kim. Supervision: Mi-Jeong Kim. Writing-original draft: Cha-Young Lim. Writing-review \& editing: Mi-Jeong Kim, Hyeon-Sun Kim.

\section{ORCID}

Mi-Jeong Kim, https://orcid.org/0000-0002-5309-1853

Cha-Young Lim, https://orcid.org/0000-0001-9345-7349

Hyeon-Sun Kim, https://orcid.org/0000-0003-1403-2217

\section{Acknowledgements}

This study was supported by research fund from, Vision College of Jeonju, 2019.

\section{References}

1. Kim MJ, Lim CY, Son JL: Effect of emotional labor on somatization among dental hygienists in an area. J Dent Hyg Sci 19: 113-121, 2019. https://doi.org/10.17135/jdhs.2019.19.2.113

2. Oh YJ, Choi YH: Effects of emotional labor, job stress and burnout on somatization in nurses: in convergence era. J Digit Converg 13: 415-424, 2015. https://doi.org/10.14400/JDC.2015.13.10.415

3. Park HY, Ko HJ, Kim HJ: Relationship with the emotiona llabor and stress and anxiety to the characteristics of dental hygienist job. Asia Pac J Multimed Serv Converg Art Humanit Sociol 7: 819-828, 2017.

4. Kang $\mathrm{OH}$ : The determinants of intent to leave of dental 
hygienists at dental clinics. J Dent Hyg Sci 6: 107-111, 2006.

5. Won YS, Oh HN: The effects of job stress and psychosocial stress among dental hygienists. J Dent Hyg Sci 15: 679-687, 2015.

https://doi.org/10.17135/jdhs.2015.15.5.679

6. Hong SM, Kim HK, Ahn YS: A study on the occupational stress, health status and somatization for dental hygienist. J Dent Hyg Sci 9: 295-302, 2009.

7. Park SK: Guidelines for supervisors for the day-to-day management of job stress. Korea Occupational Safety and Health Agency, Ulsan, pp.1-6, 2011.

8. Willmot M: The new ward manager: an evaluation of the changing role of the charge nurse. J Adv Nurs 28: 419-427, 1998. https://doi.org/10.1046/j.1365-2648.1998.00635.x

9. Kim YC, Chung HK, Lee SH: A study on the life stress effects on psychiatric symptoms and physical condition in normal subjects. Korean Neuropsychiatr Assoc 28: 282-291, 1989.

10. Lipowski Z J: Somatization: the concept and its clinical application. Am J Psychiatry 145: 1358-1368, 1988. http://doi.org/10.1176/ajp.145.11.1358

11. Park MM, Han SJ: Relations of job satisfaction with emotional labor, job stress, and personal resources in home healthcare nurses. J Korean Acad Community Health Nurs 24: 51-61, 2013.

http://doi.org/10.12799/jkachn.2013.24.1.51

12. Lee JY, Chi MW: Relation among emotional labors's job stress, role conflict, ego-resilience and job turnover. J Korea Contents Assoc 12: 191-200, 2012. http://doi.org/10.5392/JKCA.2012.12.06.191

13. Kim IS: The role of self-efficacy and social support in the relationship between emotional labor and burn out, turn over intention among hospital nurses. J Korean Acad Nurs Admin 15: 515-526, 2009.

14. Kim JH, Oh NR, Jung MA: A factor analysis on job stress level in dental hygienists. J Korea Acad Ind cooper Soc 13: 1220-1228, 2012.
http://doi.org/10.5762/KAIS.2012.13.3.1220

15. Muldary TW: Burnout among health professionals: manifestations and management. Appleton-Century-Crofts, Norwalk, 1983.

16. Nam YO, Na YS: Factors affecting dental hygienists's stress at public health center in Chonbuk province. J Korean Soc Health Educ Promot 17: 125-149, 2000.

17. Chang SJ, Koh SB, Kang DM, et al.: Developing an occupational stress scale for Korean employees. Korean J Occup Environ Med 17: 297-317, 2005.

18. Oh HJ: Effect of emotional labor and job stress on health problem of oral health professionals. Unpublished master's thesis, Changwon National University, Changwon, 2016.

19. Kim KL, Kim JH, Won HT: Simple mental diagnostic test (SCL-90-R), Korean standardization research. Jung Ang Juk Sung Publisher, Seoul, pp.449-458, 1984.

20. Lee HO, Lim CH, Ju OJ, Kim YI, Lee HK: A study on factors related to the job satisfaction of dental hygienists in $\mathrm{J}$ region. $\mathrm{J}$ Dent Hyg Sci 6: 285-293, 2006.

21. Song YS, Son HK, Kwon HK: A study of the socio demographic factors influencing job satisfaction of dental hygienists. J Korean Acad Oral Health 19: 457-474, 1995.

22. Yoon SU, Hong YH: The relationship between job stress and social-psychosocial stress among dental-workers in some area. J Korean Acad Dent Hyg 12: 137-149, 2010.

23. Lee HO, Ju OJ, Kim YI: An analysis on factors related to the job satisfaction of dental hygienists at J region. J Dent Hyg Sci 7: 65-72, 2007.

24. Jeong SB, Choi EM, Choi JS: The effects of emotional labor on burnout, turnover intention, and job satisfaction among clinical dental hygienists. J Korean Acad Oral Health 38: 50-58, 2014 https://doi.org/10.11149/jkaoh.2014.38.1.50

25. Lee CK, Yoon DY: A study on job burnout and work engagement of job counsellor: based on the job demandsresources model. Korean Corp Manag Rev 22: 169-186, 2015. 